\title{
Prioritas Arahan Pemanfaatan Ruang Kawasan Sekitar Jalan Lingkar Ambarawa berdasarkan Potensi dan Limitasi
}

\author{
Pingkan Ellotama Tunjung Biru ${ }^{1}$ \\ Departemen Perencanaan Wilayah dan Kota, Fakultas Teknik \\ Universitas Diponegoro, Semarang, Indonesia
}

\section{Ragil Haryanto \\ Departemen Perencanaan Wilayah dan Kota, Fakultas Teknik Universitas Diponegoro, Semarang, Indonesia}

Artikel Masuk : 30 November 2016

Artikel Diterima : 14 Maret 2017

Tersedia Online : 27 Maret 2017

\begin{abstract}
Abstrak: Perkembangan Jalan Lingkar Ambarawa memicu terjadinya peningkatan alih fungsi lahan dari lahan tidak terbangun menjadi lahan terbangun di kawasan sekitarnya. Studi bertujuan untuk mengkaji prioritas pemanfaatan ruang di daerah Jalan Lingkar Ambarawa berdasarkan potensi dan limitasi dengan mempertimbangkan persepsi para ahli. Studi dilakukan menggunakan metode kuantitatif dengan analisis Analytical Hierarchy Process (AHP). Hasil studi menunjukkan bahwa kriteria tata ruang adalah kriteria utama dalam menentukan arahan pemanfaatan ruang di kawasan sekitar Jalan Lingkar Ambarawa. Hasil pembobotan untuk masing-masing subkriteria yang membandingkan antara potensi dan limitasi juga menunjukkan bahwa responden lebih memilih untuk memprioritaskan skenario untuk menjaga daerah sekitar Jalan Lingkar Ambarawa sebagai kawasan tidak terbangun. Selain itu, skenario alternatif menyatakan bahwa kawasan sekitar Jalan Lingkar Ambarawa agar diarahkan sebagai kawasan pariwisata dengan tetap memperhatikan keseimbangan lingkungan. Rencana tata ruang wilayah berperan penting dalam menentukan arahan pemanfaatan ruang di kawasan sekitar Jalan Lingkar Ambarawa.
\end{abstract}

Kata Kunci: Analytical Hierarchy Process (AHP), Jalan Lingkar Ambarawa, prioritas arahan pemanfaatan ruang

Abstract: The development of Ambarawa Ring Road leads to the increase of land conversion from vacant to the built-up area around. The study aims to analyze the spatial use priorities in Ambarawa Ring Road area based on the potentials and limitations by considering the experts' perceptions. This study was conducted using a quantitative method of Analytical Hierarchy Process (AHP). The findings indicate that the spatial criteria are the main criteria for determining the spatial utilization in Ambarawa Ring Road. The weighted result for each subcriterion that compares the potentials and limitations also shows that respondents prefer to

\footnotetext{
${ }^{1}$ Korespondensi Penulis: Departemen Perencanaan Wilayah dan Kota, Universitas Diponegoro, Semarang, Indonesia Email: pingkan.ellotama16@pwk.undip.ac.id
} 


\section{Prioritas Arahan Pemanfaatan Ruang Kawasan Sekitar Jalan Lingkar Ambarawa berdasarkan Potensi..}

prioritize the scenario to maintain the area around Ambarawa Ring Road as a vacant area. In addition, the alternative scenario reveals that the area around the Ambarawa Ring Road directed to developing tourism area while considering the environmental balance. Spatial planning plays a significant role in determining the direction of space utilization around Ambarawa Ring Road.

Keywords: Analytical Hierarchy Process (AHP), Ambarawa Ring Road, spatial utilization priority

\section{Pendahuluan}

Pembangunan dan perkembangan jaringan jalan pada suatu kawasan dapat memicu perkembangan aktivitas dan guna lahan di kawasan sekitarnya. Ini dikarenakan jalan berperan penting sebagai prasarana untuk memudahkan aktivitas dalam melakukan perjalanan dari satu tempat ke tempat lain serta melakukan distribusi manusia maupun barang. Penggunaan lahan dan tutupan lahan akan berubah dikarenakan adanya perkembangan aktivitas manusia yang membutuhkan pengembangan jaringan jalan (Oruonye, 2014; Patarasuk \& Binford, 2012; Tamin 2000). Perkembangan jaringan jalan akan mengubah area di sekitarnya, seperti hutan dan lahan pertanian (Patarasuk \& Binford, 2012). Beberapa penelitian sebelumnya juga menunjukkan bahwa perkembangan jaringan jalan berfungsi untuk meningkatkan perekonomian akan menyebabkan perubahan fungsi guna lahan sehingga ada keterkaitan kuat antara jalan dan interaksi guna lahan (Geist \& Lambin, 2002; Vickerman, Spiekermann, \& Wegener, 1999). Kebutuhan lahan untuk hunian dan aktivitas lain serta kebutuhan untuk mendapatkan kemudahan akses dalam melakukan kegiatan sehari-hari, memicu berkembangnya alih fungsi lahan dari lahan nonterbangun menjadi lahan terbangun di sekitar koridor jaringan jalan (Tamin, 2000). Perubahan guna lahan bersifat dinamis sejalan dengan interaksi manusia dengan lingkungan terbangun (Verburg, van Eck, de Nijs, Dijst, \& Schot, 2004). Lebih lanjut, Václavík dan Rogan (2009) bahwa fungsi guna lahan dipengaruhi oleh perkembangan aktivitas ekonomi yang akhirnya berdampak pada manajemen guna lahan.

Salah satu fenomena perkembangan aktivitas dan guna lahan di sekitar koridor jalan yang dapat diamati adalah perkembangan aktivitas pada kawasan sekitar Jalan Lingkar Ambarawa. Jalan Lingkar Ambarawa diresmikan tahun 2012 sebagai langkah mengatasi kemacetan yang terjadi pada ruas jalan utama di Ambarawa. Kawasan di sekitar Jalan Lingkar Ambarawa memiliki potensi untuk berkembang sebagai kawasan terbangun karena memiliki beragam daya tarik, seperti lokasi yang strategis dan kemudahan aksesibilitas.

Pembangunan Jalan Lingkar Ambarawa sebagian besar dikelilingi oleh lahan pertanian produktif dan berdekatan dengan Danau Rawa Pening yang mana ditetapkan sebagai kawasan konservasi menyebabkan terbatasnya pemanfaatan ruang di sekitar Jalan Lingkar Ambarawa. Namun demikian, dari sisi lingkungan, Danau Rawa Pening termasuk dalam salah satu dari 15 danau di Indonesia yang mengalami permasalahan kerusakan ekosistem danau, seperti sedimentasi, pendangkalan, peningkatan eceng gondok, batas sempadan danau yang tidak jelas, dan lain sebagainya sehingga perlu dilakukan upaya konservasi dengan ketat. Kawasan sekitar Danau Rawa Pening juga rawan terjadi luapan dari Danau Rawa Pening dan menggenangi lahan pertanian di sekitarnya dan sungai-sungai yang menjadi inlet Danau Rawa Pening juga beberapa kali meluap ke permukiman warga setempat (Soeprobowati, 2012). Area inlet danau juga merupakan celah masuknya bahan polutan yang dapat mengganggu kelestarian alam (Kutarga, Nasution, Tarigan, \& Sirojuzilam, 2008).

Menurut Rostika, Avenzora, Masyamsir, dan Yustiati (2012), sebenarnya kawasan danau dan sekitarnya dapat dimanfaatkan untuk beberapa macam peruntukkan, seperti 
budidaya perikanan serta untuk wisata terutama untuk ekowisata dengan tetap memperhatikan keseimbangan lingkungan. Hal tersebut sesuai juga dengan ketetapan Undang-Undang Nomor 22 Tahun 1982 tentang Tata Pengaturan Air dan Peraturan Pemerintah Nomor 35 Tahun 1991 tentang Sungai yang memperbolehkan beberapa jenis pemanfaatan ruang di sekitar kawasan danau di antaranya untuk upaya konservasi, penelitian, rehabilitasi, objek wisata, budidaya perikanan, dan lain-lain yang sejenis. Namun demikian, untuk menjamin keberlanjutan fungsi danau diperlukan langkah pengamanan danau dan kawasan di sekitarnya melalui tata ruang. Tata ruang bagi kawasan danau dan sekitarnya bermanfaat untuk menghindarkan konflik pemanfaatan sumber daya dan degradasi lingkungan. Ini dikarenakan kawasan sekitar danau memiliki fungsi yang cukup strategis untuk dikembangkan. Hasil penelitian Kumurur (2009) mengungkapkan bahwa kawasan daratan sekitar danau rentan mengalami konversi pemanfaatan ruang terutama menjadi kawasan budidaya.

Adanya fenomena perkembangan aktivitas dan perubahan penggunaan lahan di sekitar Jalan Lingkar Ambarawa dikhawatirkan akan berpengaruh terhadap menurunnya luasan lahan pertanian produktif secara signifikan serta dapat berdampak pada degradasi lingkungan di Danau Rawa Pening bahkan memperparah kondisi yang saat ini telah terjadi. Hal ini melihat kondisi penggunaan lahan di sekitar Jalan Lingkar Ambarawa yang cukup berpotensi untuk dikembangkan dan diubah menjadi kawasan budidaya dengan adanya dukungan Danau Rawa Pening. Beberapa bangunan yang berdiri di sekitar kawasan Jalan Lingkar Ambarawa juga diketahui telah berdiri pada kawasan yang bukan diperuntukkan sebagai kawasan terbangun sebagaimana ditetapkan dalam Peraturan Daerah Kabupaten Semarang Nomor 6 Tahun 2011 mengenai Rencana Tata Ruang Wilayah Kabupaten Semarang Tahun 2011-2031. Namun, hingga saat ini tidak ada tindakan untuk penertiban bangunan. Padahal, rencana tata ruang yang dapat diimplementasikan dengan baik bermanfaat untuk pengaturan zonasi pemanfaatan kawasan di sekitar danau diperlukan untuk menghindarkan konflik kepentingan dan kerusakan lingkungan.

Penelitian bertujuan untuk menentukan prioritas pemanfaatan ruang untuk kawasan sekitar Jalan Lingkar Ambarawa berdasarkan faktor potensi dan limitasi yang dimiliki dengan mempertimbangkan persepsi dan hasil prioritasi dari para ahli. Penelitian ini dapat menjadi masukkan bagi pemangku kepentingan untuk tetap mempertahankan kawasan di sekitar Jalan Lingkar Ambarawa sebagai kawasan nonterbangun atau mendukung dilakukannya pengembangan sebagai kawasan terbangun sesuai dengan fenomena alih fungsi lahan yang telah terjadi.

\section{Metode Penelitian}

Penelitian menggunakan metode kuantitatif dengan teknik analisis Analytic Hierarchy Process (AHP) atau dalam Bahasa Indonesia dikenal dengan Proses Hirarki Analitik. Analisis AHP merupakan sebuah metode analisis yang berfungsi untuk membantu para pemangku kebijakan maupun pengambil keputusan untuk mengidentifikasi dan menetapkan sebuah keputusan berdasarkan penstrukturan beberapa kriteria yang berkaitan sehingga didapat prioritas dalam pengambilan keputusan (Saaty, 1991). Dalam penelitian ini, analisis AHP digunakan untuk membantu menentukan prioritas arahan pemanfaatan ruang kawasan sekitar Jalan Lingkar Ambarawa berdasarkan potensi dan limitasi yang dimiliki dengan menyusun hirarki prioritas, kriteria, subkriteria, dan alternatif. Dalam pelaksanaan kegiatan analisis menggunakan AHP terdapat tahapan-tahapan yang harus dilakukan:

1. Merumuskan tujuan penelitian berdasarkan rumusan masalah yang diangkat

2. Menentukan kriteria yang terkait dengan tujuan yang ingin dicapai dalam penelitian

3. Menentukan subkriteria atau alternatif pemilihan 


\section{Prioritas Arahan Pemanfaatan Ruang Kawasan Sekitar Jalan Lingkar Ambarawa berdasarkan Potensi...}

4. Menyusun hirarki prioritas

5. Menyusun matriks perbandingan berpasang

6. Melakukan pembobotan kriteria

7. Melakukan pembobotan alternatif

8. Menentukan consistency ratio

9. Menarik kesimpulan

Untuk mengisi matriks perbandingan berpasang Saaty (1991) telah menetapkan bilangan yang menggambarkan prioritas suatu elemen atas elemen lainnya dengan menggunakan skala 1-9 dengan disertai penjelasannya seperti di Tabel 1. Hirarki dan matriks perbandingan berpasang yang telah tersusun kemudian akan dianalisis untuk menentukan alternatif dengan melakukan beberapa langkah-langkah perhitungan dimulai dari membuat matrikss perbandingan berpasang yang menunjukkan pengaruh antar elemen pada kriteria yang dibandingkan, kemudian dilakukan perhitungan nilai eigen dan eigen vektor. Langkah terakhir adalah melakukan perhitungan rasio konsistensi untuk mengetahui tingkat inkonsistensi data yang didapat. Penelitian ini menyertakan hasil pembobotan dari 13 responden. Perhitungan analisis akan dilakukan dengan menghitung hasil pada tiap-tiap responden untuk kemudian di rata-rata.

\section{Tabel 1. Skala Banding secara Berpasang}

\begin{tabular}{|c|c|c|}
\hline $\begin{array}{c}\text { Intensitas } \\
\text { Kepentingan }\end{array}$ & Definisi & Penjelasan \\
\hline 1 & Kedua elemen sama pentingnya & $\begin{array}{l}\text { Dua mempunyai pengaruh yang sama besar } \\
\text { terhadap tujuan }\end{array}$ \\
\hline 3 & $\begin{array}{l}\text { Elemen yang satu sedikit lebih } \\
\text { penting dari elemen lainnya }\end{array}$ & $\begin{array}{l}\text { Pengalaman dan penilaian sedikit menyokong } \\
\text { satu elemen atas yang lainnya }\end{array}$ \\
\hline 5 & $\begin{array}{l}\text { Elemen yang satu lebih penting } \\
\text { dari elemen lainnya }\end{array}$ & $\begin{array}{l}\text { Pengalaman dan penilaian sangat kuat } \\
\text { menyokong satu elemen dibandingkan elemen } \\
\text { lainnya }\end{array}$ \\
\hline 7 & $\begin{array}{l}\text { Satu elemen jelas lebih mutlak } \\
\text { penting daripada elemen lainnya }\end{array}$ & $\begin{array}{l}\text { Satu elemen yang kuat disokong dan dominan } \\
\text { terlihat dalam praktek }\end{array}$ \\
\hline 9 & $\begin{array}{l}\text { Satu elemen mutlak penting } \\
\text { daripada elemen lainya }\end{array}$ & $\begin{array}{l}\text { Bukti yang mendukung elemen yang satu } \\
\text { terhadap elemen yang lain memiliki tingkat } \\
\text { penegasan tertinggi yang mungkin menguatkan }\end{array}$ \\
\hline $2,4,6,8$ & $\begin{array}{l}\text { Nilai-nilai antara dua nilai } \\
\text { pertimbangan yang berdekatan }\end{array}$ & $\begin{array}{l}\text { Nilai ini diberikan jika ada dua komporomi } \\
\text { diantara dua pilihan }\end{array}$ \\
\hline Kebalikan & \multicolumn{2}{|c|}{$\begin{array}{l}\text { Jika untuk aktivitas } i \text { mendapat satu angka bila dibandingkan dengan aktivitas } j \text {, maka } \\
j \text { mempunyai nilai kebalikan bila dibandingkan dengan } i\end{array}$} \\
\hline
\end{tabular}

Sumber: Saaty, 1991

Berikut adalah penjabaran dari langkah-langkah untuk melakukan perhitungan AHP menurut Saaty \& Kearns (1985):

1. Menghitung Nilai Eigen Vektor

Sebelum melakukan perhitungan eigen vektor terlebih dahulu membuat matriks perbandingan berpasangan bobot elemen seperti dicontohkan pada Tabel 2, dimana elemen A dengan faktor $i$ dibandingkan dengan elemen A faktor $j$ sehingga didapat rumus sebagai berikut:

$$
a(\mathrm{ij})=\mathrm{Ai} / \mathrm{Aj} \text {, dimana } \mathrm{i} \text { dan } \mathrm{j}=1,2,3 \ldots . \mathrm{n}
$$


Hasil perbandingan berpasang antar elemen A di atas kemudian dinyatakan dalam vektor w antara lain $\mathrm{W} 1, \mathrm{~W} 2, \mathrm{~W} 3, \ldots . . \mathrm{Wn}$ sehingga nilai intensitas elemen dinyatakan dalam aij yang menyatakan kepentingan factor $i$ terhadap $j$. Sementara itu, untuk menyatakan kepentingan faktor $j$ terhadap $k$ dapat dinyatakan dalam ajk. Agar hasil yang didapat nantinya konsisten, maka aij harus sama dengan ajk, dengan demikian dapat dihitung menggunakan rumus:

$$
a j=\sum_{i=1}^{n} a i j
$$

Selanjutnya nilai Eigen (Wi) pada tiap baris dapat dihitung menggunakan rumus:

$$
W i=n \sqrt{\text { ai1 } 1 \text { xai } 2 x a i 3 x \ldots x a i n}
$$

Dari hasil perhitungan Wi di atas maka kemudian dilanjutkan dengan mencari nilai eigen yang dinormalisasi $(\mathrm{Xi})$ pada tiap baris dengan rumus:

$$
x i=\frac{W i}{\sum W i}
$$

Sehingga nilai eigen vektor terbesar dapat dicari dengan menggunakan rumus:

$$
\lambda \text { maks }=\sum \text { aij } . \mathrm{Xj}
$$

2. Menghitung Nilai Konsistensi

Perhitungan nilai konsistensi digunakan untuk mengetahui tingkat konsistensi hasil pembobotan nilai yang dilakukan oleh para responden, semakin kecil dan mendekati $\leq 0,1$ maka data tersebut dinyatakan semakin konsisten. Untuk menghitung konsistensi dinyatakan dalam rumus:

$$
C I=\frac{\lambda m a k s-n}{n-1}
$$

Dimana:

$\mathrm{CI} \quad=$ Consistency Index (Indekss Konsistensi)

$\lambda$ maks $=$ Nilai Eigen Vektor Maksimum

$\mathrm{n} \quad=$ Ukuran matriks

Setelah didapat indekss konsistensi, kemudian dilanjutkan dengan menghitung rasio konsistensi yang dinyatakan dalam rumus:

$$
C R=\frac{C I}{R I}
$$


16 Prioritas Arahan Pemanfaatan Ruang Kawasan Sekitar Jalan Lingkar Ambarawa berdasarkan Potensi...

Dimana :

$\mathrm{CR}=$ Consistency Ratio (Rasio Konsistensi)

CI = Consistency Index (Indeks Konsistensi)

RI $\quad=$ Randomly generated matrices (Matriks Indeks Random)

Pada matriks Indeks Random setidaknya terdapat 15 indeks random yang telah ditentukan tiap ordo matriks (n) sebagaimana di Tabel 2.

Tabel 2.Matriks Indeks Random

\begin{tabular}{c|c|c|c|c|c|c|c|c|c|c|c|c|c|c|c}
\hline $\mathbf{n}$ & 1 & 2 & 3 & 4 & 5 & 6 & 7 & 8 & 9 & 10 & 11 & 12 & 13 & 14 & 15 \\
\hline R1 & 0,00 & 0,00 & 0,58 & 0,90 & 1,12 & 1,24 & 1,32 & 1,41 & 1,45 & 1,49 & 1,51 & 1,48 & 1,56 & 1,57 & 1,59 \\
\hline
\end{tabular}

Penyusunan hirarki terdiri atas 3 tingkat antara lain tujuan, kriteria, subkriteria, dan alternatif. Kriteria, subkriteria, dan alternatif yang dipilih didasarkan pada hasil kajian literatur sebelumnya yang kemudian disesuaikan dengan kondisi yang ada di lokasi penelitian. Gambar 1 menggambarkan model hirarki yang disertai penjelasan kriteria, subkriteria, dan alternatif yang digunakan.

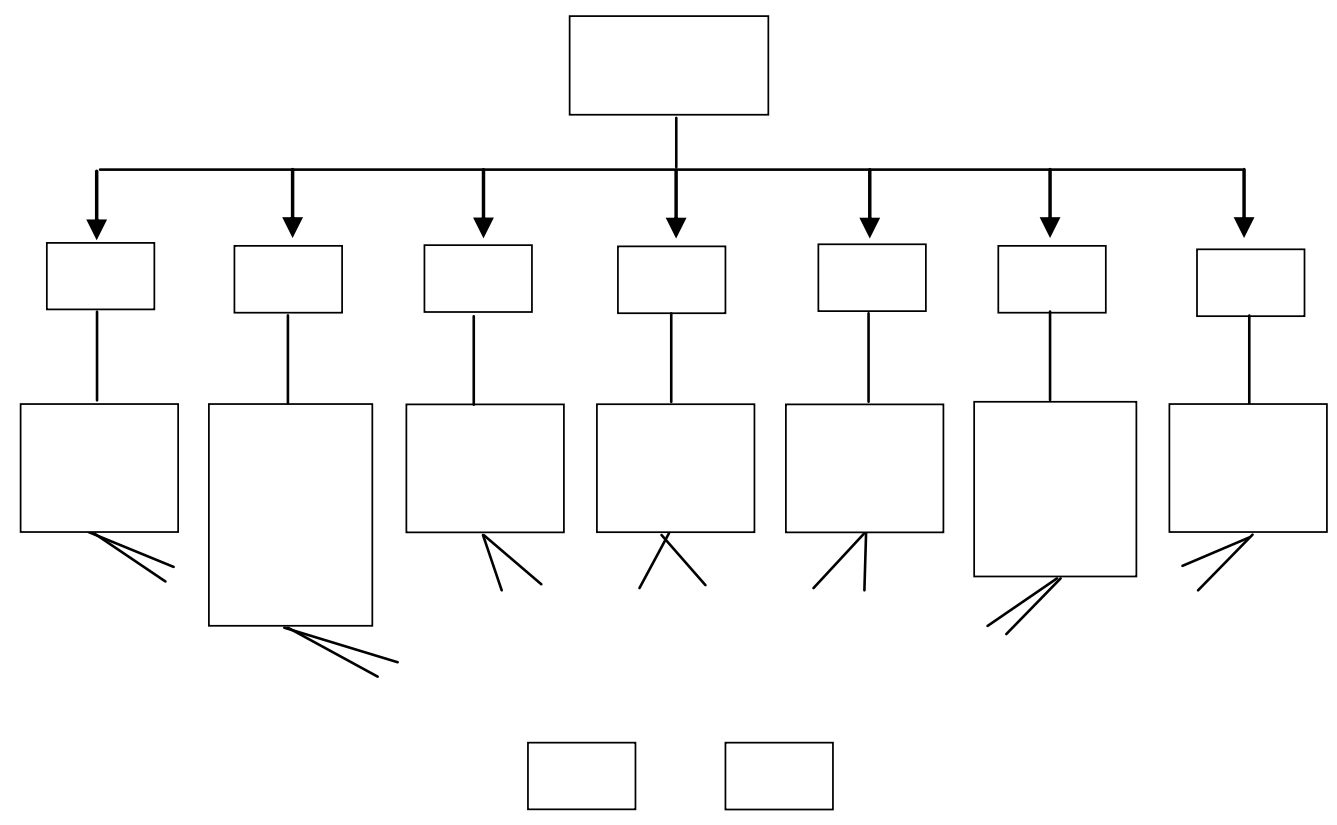

Sumber: Analisis Penyusun, 2016

\section{Gambar 1. Bentuk Hirarki AHP dalam Penelitian}

- $\quad$ Tingkat I: Tujuan

Fokus atau tujuan yang ingin dicapai adalah merumuskan arahan prioritas skenario pemanfaatan ruang kawasan sekitar Jalan Lingkar Ambarawa berdasarkan potensi dan limitasi yang dimiliki.

- $\quad$ Tingkat II: Kriteria (C) 
Kriteria yang ditetapkan dalam penelitian ini didasarkan pada hasil kajian literatur oleh Budiharsono (2005) mengenai kriteria pengembangan wilayah yang kemudian disesuaikan dengan kebutuhan penelitian dan kondisi di lapangan antara lain :

$\mathrm{C} 1$ : aspek tata ruang

C2 : aspek kelembagaan

C3 : aspek biogeofisik

C4 : aspek lingkungan

C5 : aspek lokasi

C6 : aspek ekonomi

C7 : aspek sosial

- $\quad$ Tingkat III: Subkriteria

Penentuan subkriteria ini didasarkan dari hasil kajian literatur dari Budiharsono (2005) tentang kriteria pengembangan wilayah dan Hasim, Sapei, Budiharsono, dan Wardiatno, 2012) tentang dimensi dan faktor yang yang berpengaruh dalam keberlanjutan pengelolaan danau yang kemudian disesuaikan dengan kondisi yang ada di lokasi penelitian. Tiap-tiap aspek pada subkriteria ini memuat dua atau lebih aspek yang saling bertolak belakang antara aspek potensi dengan aspek limitasi yang nantinya akan dibandingkan untuk menentukan prioritasnya. Subkriteria hasil dari perincian dari kriteria yang digunakan antara lain:

a. Tata ruang (C1):

SC1.1 : Dukungan adanya perubahan aturan zonasi pemanfaatan ruang sekitar Jalan Lingkar Ambarawa agar dapat direncanakan sebagai kawasan pengembangan lahan terbangun secara lebih luas namun tetap terarah sesuai dengan hasil kajian mengenai pola pemanfaatan ruang yang tepat

SC1.2 : Pelaksanaan aturan zonasi pemanfaatan ruang yang telah ditetapkan dalam Rencana Tata Ruang Wilayah Kabupaten Semarang saat ini.

b. Kelembagaan (C2):

SC2.1 : Pihak pemerintah selaku pemangku kebijakan

SC2.2 : Pihak swasta selaku pelaku usaha di bidang developer perumahan maupun perdagangan dan jasa di kawasan sekitar Jalan Lingkar Ambarawa

SC2.3 : Pihak akademisi selaku ahli dalam disiplin ilmu

SC2.4 : Masyarakat selaku pihak yang bertempat tinggal di lokasi penelitian

c. Biogeofisik (C3):

SC3.1: Topografi datar sehingga cocok untuk dikembangkan sebagai kawasan terbangun

SC3.2 : Permasalahan rawan bencana banjir dan kerusakan fisik Danau Rawa Pening

d. Lingkungan (C4):

SC4.1: Potensi pemanfaatan ruang di kawasan sekitar Jalan Lingkar Ambarawa untuk dikembangkan sebagai kawasan budidaya (hunian, perdagangan jasa, komersil)

SC4.2 : Kemungkinan terjadinya degradasi lingkungan apabila dikembangkan sebagai kawasan terbangun

e. Lokasi (C5):

SC5.1: Kemudahan aksesibilitas untuk menunjang aktivitas masyarakat setempat

SC5.2 : Berdekatan dengan Danau Rawa Pening yang ditetapkan sebagai kawasan konservasi-perlindungan setempat sehingga terdapat pembatasan aktivitas pemanfaatan ruang

f. Ekonomi (C6):

SC6.1: Kegiatan perekonomian yang berkembang. Sebagian besar masyarakat bekerja pada sektor pertanian (baik pertanian pangan maupun perikanan) serta pada sektor jasa. 


\section{Prioritas Arahan Pemanfaatan Ruang Kawasan Sekitar Jalan Lingkar Ambarawa berdasarkan Potensi...}

SC6.2 : Potensi pemanfaatan sumber daya perairan Danau Rawa Pening. Ketersediaan sumber daya di Danau Rawa Pening yang dapat dimanfaatkan masyarakat dan meningkatkan nilai ekonomi

SC6.3 : Ketersediaan sarana prasarana seperti kondisi jaringan jalan, listrik, air bersih, telekomunikasi, sarana perdagangan dan jasa untuk menunjang aktivitas perekonomian masyarakat

g. Sosial (C7):

SC7.1: Kebutuhan masyarakat untuk memanfaatkan lahan di sekitar Jalan Lingkar Ambarawa guna dikembangkan sebagai lahan terbangun seperti hunian maupun aktivitas komersial sebagai dampak dari pertumbuhan penduduk dan peningkatan aktivitas di sekitar Jalan Lingkar Ambarawa

SC7.2 : Upaya masyarakat untuk tetap melestarikan kondisi eksisting kawasan sekitar Jalan Lingkar Ambarawa yang sebagian besar masih berupa lahan pertanian

- $\quad$ Tingkat IV: Alternatif Skenario

Penentuan alternatif skenario didasarkan pada beberapa pertimbangan diantaranya yang pertama mengadopsi ketentuan teknis zonasi pemanfaatan ruang pada Peraturan Menteri Pekerjaan Umum Nomor 20/PRT/M/2011 tentang Pedoman Penyusunan Rencana Detail Tata Ruang dan Peraturan Zonasi Kabupaten Kota. Kedua didasarkan pada hasil telaah dokumen pada Peraturan Daerah Kabupaten Semarang Nomor 6 Tahun 2011 mengenai Rencana Tata Ruang Wilayah Kabupaten Semarang Tahun 2011-2031 yang menetapkan agar sebagian besar kawasan sekitar Jalan Lingkar Ambarawa tetap dipertahankan sebagai kawasan nonterbangun. Ketiga, penentuan alternatif skenario juga didasarkan pada hasil observasi peneliti di lokasi penelitian yang mana berdasarkan kondisi di lapangan ternyata tidak sesuai dengan arahan zonasi pada Rencana Tata Ruang Wilayah Kabupaten Semarang karena pada beberapa lokasi justru mengalami perubahan guna lahan yang tidak sesuai dengan zonasi peruntukkannya. Berikut adalah dua alternatif yang telah ditetapkan sebagai arahan prioritas pemanfaatan ruang untuk kawasan sekitar Jalan Lingkar Ambarawa, yaitu:

A1: Mempertahankan kondisi eksisting: kawasan sekitar Jalan Lingkar Ambarawa tidak boleh dikembangkan sebagai kawasan terbangun dan tetap mempertahankan kondisi saat ini yang sebagian besar merupakan lahan pertanian.

A2: Pengembangan bersyarat: kawasan sekitar Jalan Lingkar Ambarawa dapat dikembangkan sebagai kawasan terbangun namun harus memperhatikan zonasi dan keseimbangan lingkungan.

\section{Hasil dan Pembahasan}

Tahapan dalam perhitungan untuk menentukan alternatif arahan pemanfaatan ruang yang pertama adalah dengan menghitung prioritas kriteria. Setelah itu, menghitung prioritas untuk tiap-tiap subkriteria. Langkah terakhir adalah menghitung prioritas untuk alternatif skenario arahan pemanfaatan ruang kawasan sekitar Jalan Lingkar Ambarawa.

1. Penentuan Prioritas Kriteria

Berdasarkan hasil perhitungan diketahui bahwa kriteria tata ruang memiliki besaran bobot tertinggi dalam prioritas dengan interval perolehan nilai yang cukup signifikan dibandingkan dengan kriteria lainnya, yaitu sebesar 0,4271 yang menunjukkan bahwa kriteria tata ruang memiliki pengaruh yang sangat besar dalam rencana pengembangan dan program pembangunan suatu wilayah. Dalam penelitian ini kriteria tata ruang memuat atas peraturan daerah mengenai Rencana Tata Ruang Wilayah Kabupaten Semarang dan rencana zonasi pada kawasan sekitar Jalan Lingkar Ambarawa. Berdasarkan hal tersebut, sebagian besar responden menilai bahwa peraturan daerah tentang RTRW dan rencana 
zonasi merupakan hal terpenting yang mana dijadikan sebagai dokumen pedoman agar segala bentuk pemanfaatan ruang dan pembangunan mengacu pada zonasi yang telah ditetapkan dalam RTRW. Selain itu, kriteria tata ruang juga dianggap sebagai kriteria yang dapat mewakili kriteria-kriteria lainnya karena dalam kriteria tata ruang berisikan kebijakan yang sudah didasarkan pada kajian secara menyeluruh dari berbagai kriteria lain, seperti kriteria fisik, ekonomi, sosial, lingkungan, dan lain sebagainya. Adapun urutan prioritas kedua hingga ketujuh secara berurutan ditempati oleh kriteria biogeofisik, lingkungan, ekonomi, sosial, lokasi, dan kelembagaan. Hal ini sejalan dengan pendapat Kutarga et al. (2008) dan Wahyuhana \& Sugiri (2014) bahwa rencana tata ruang berperan penting dalam menjelaskan fungsi pelayanan kawasan dan konektivitas wilayah. Adapun untuk hasil perhitungan prioritas kriteria terjabarkan di Tabel 3.

Tabel 3. Matriks Perhitungan Kriteria

\begin{tabular}{ccccccccccccc}
\hline & \multirow{2}{*}{ C1 } & C2 & C3 & C4 & C5 & C6 & C7 & $\begin{array}{c}\text { Vektor } \\
\text { Eigen }\end{array}$ & $\begin{array}{c}\text { Vektor } \\
\text { Prioritas }\end{array}$ & $\begin{array}{c}\boldsymbol{\lambda} \\
\text { maks }\end{array}$ & CI & CR \\
\hline C1 & 0,463 & 0,459 & 0,561 & 0,483 & 0,351 & 0,338 & 0,334 & 2,990 & $\mathbf{0 , 4 2 7 1}$ & & & \\
C2 & 0,035 & 0,035 & 0,035 & 0,030 & 0,024 & 0,036 & 0,049 & 0,243 & 0,0346 & & & \\
C3 & 0,130 & 0,156 & 0,157 & 0,228 & 0,195 & 0,187 & 0,180 & 1,231 & 0,1759 & & & \\
C4 & 0,157 & 0,192 & 0,113 & 0,164 & 0,291 & 0,289 & 0,239 & 1,445 & 0,2064 & 7,2 & 0,04 & 0,03 \\
C5 & 0,054 & 0,059 & 0,033 & 0,023 & 0,041 & 0,048 & 0,049 & 0,308 & 0,0440 & 683 & 47 & 39 \\
C6 & 0,091 & 0,064 & 0,056 & 0,038 & 0,056 & 0,067 & 0,099 & 0,471 & 0,0673 & & & \\
C7 & 0,070 & 0,036 & 0,044 & 0,035 & 0,042 & 0,034 & 0,051 & 0,312 & 0,0446 & & & \\
Jumlah & $\mathbf{1 , 0 0 0}$ & $\mathbf{1 , 0 0 0}$ & $\mathbf{1 , 0 0 0}$ & $\mathbf{1 , 0 0 0}$ & $\mathbf{1 , 0 0 0}$ & $\mathbf{1 , 0 0 0}$ & $\mathbf{1 , 0 0 0}$ & $\mathbf{7 , 0 0 0}$ & $\mathbf{1 , 0 0 0}$ & & & \\
\hline
\end{tabular}

2. Penentuan Prioritas Sub-Subkriteria

Berdasarkan analisis pembobotan untuk tiap-tiap subkriteria, diketahui bahwa hampir seluruh subkriteria menempatkan aspek limitasi sebagai prioritas yang lebih tinggi dibandingkan aspek potensi. Hasil ini menunjukkan bahwa para responden menyadari terhadap berbagai keterbatasan yang ada sehingga akan berpengaruh terhadap rencana untuk pengembangan kawasan sekitar Jalan Lingkar Ambarawa. Berikut adalah hasil perhitung masing-masing subkriteria dalam menentukan arahan pemanfaatan ruang kawasan sekitar Jalan Lingkar Ambarawa:

1) Prioritas Subkriteria Tata Ruang

Perbandingan antara subkriteria tata ruang lebih memprioritaskan subkriteria kedua yaitu untuk tetap melaksanakan aturan zonasi pemanfaatan ruang yang telah ditetapkan dalam RTRW Kabupaten Semarang saat ini dengan nilai vektor prioritas sebesar 0,766 sehingga tidak diperlukan adanya perubahan aturan zonasi. Tabel 4 menunjukkan matriks perhitungan subkriteria tata ruang.

Tabel 4. Matriks Perhitungan Subkriteria Tata Ruang

\begin{tabular}{cccccccc}
\hline & SC1 & SC2 & VE & VP & $\boldsymbol{\lambda}$ maks & CI & CR \\
\hline SC1 & 0,234 & 0,234 & 0,469 & 0,234 & \multirow{2}{*}{2} & 0 & 0 \\
SC2 & 0,766 & 0,766 & 1,531 & $\mathbf{0 , 7 6 6}$ & & & \\
\hline
\end{tabular}


2) Prioritas Subkriteria Biogeofisik

Perbandingan antara subkriteria biogeofisik lebih memprioritaskan mengenai permasalahan rawan bencana banjir dan kerusakan fisik Danau Rawa Pening dengan nilai vektor prioritas sebesar 0,975. Tabel 5 menunjukkan matriks perhitungan subkriteria biogeofisik.

Tabel 5. Matriks Perhitungan Subkriteria Biogeofisik

\begin{tabular}{cccccccc}
\hline & SC1 & SC2 & VE & VP & $\lambda$ maks & CI & CR \\
\hline SC1 & 0,025 & 0,025 & 0,050 & 0,025 & \multirow{2}{*}{2} & 0 & 0 \\
SC2 & 0,975 & 0,975 & 1,950 & $\mathbf{0 , 9 7 5}$ & & & \\
\hline
\end{tabular}

3) Prioritas Subkriteria Lingkungan

Hasil perbandingan antara subkriteria lingkungan menunjukkan bahwa lebih memprioritaskan akan kemungkinan terjadinya degradasi lingkungan apabila kawasan sekitar Jalan Lingkar Ambarawa dikembangkan sebagai kawasan terbangun dengan nilai vektor prioritas sebesar 0,945. Tabel 6 menunjukkan matriks perhitungan subkriteria lingkungan.

Tabel 6. Matriks Perhitungan Subkriteria Lingkungan

\begin{tabular}{cccccccc}
\hline & SC1 & SC2 & VE & VP & $\lambda$ maks & CI & CR \\
\hline SC1 & 0,055 & 0,055 & 0,109 & 0,055 & 2 & 0 & 0 \\
SC2 & 0,945 & 0,945 & 1,891 & $\mathbf{0 , 9 4 5}$ & 2 & & \\
\hline
\end{tabular}

4) Prioritas Subkriteria Ekonomi

Hasil perhitungan prioritas antara subkriteria ekonomi menghasilkan prioritas mengenai potensi pemanfaatan sumber daya perairan Danau Rawa Pening untuk kegiatan sehari-hari dengan nilai vektor prioritas sebesar 0,837 dan nilai rasio konsistensi sebesar 0,042034. Tabel 7 menunjukkan matriks perhitungan subkriteria ekonomi.

Tabel 7. Matriks Perhitungan Subkriteria Ekonomi

\begin{tabular}{ccccccccc}
\hline & SC1 & SC2 & SC3 & VE & VP & $\boldsymbol{\lambda}$ maks & CI & CR \\
\hline SC1 & 0,106 & 0,104 & 0,154 & 0,364 & 0,121 & & & \\
SC2 & 0,863 & 0,848 & 0,800 & 2,510 & $\mathbf{0 , 8 3 7}$ & 3,04 & 0,02 & 0,04 \\
SC3 & 0,031 & 0,048 & 0,046 & 0,126 & 0,042 & & 438 & 2034 \\
\hline
\end{tabular}

5) Prioritas Subkriteria Sosial

Perbandingan antara subkriteria sosial menunjukkan bahwa lebih memprioritaskan upaya masyarakat untuk tetap melestarikan kondisi eksisting kawasan sekitar Jalan Lingkar Ambarawa yang sebagian besar masih berupa lahan pertaniandengan nilai vektor prioritas sebesar 0,996. Tabel 8 menunjukkan matriks perhitungan subkriteria sosial. 
Tabel 8. Matriks Perhitungan Subkriteria Sosial

\begin{tabular}{cccccccc}
\hline & SC1 & SC2 & VE & VP & $\lambda$ maks & CI & CR \\
\hline SC1 & 0,004 & 0,004 & 0,007 & 0,004 & 2 & 0 & 0 \\
SC2 & 0,996 & 0,996 & 1,993 & $\mathbf{0 , 9 9 6}$ & & & \\
\hline
\end{tabular}

6) Prioritas Subkriteria Lokasi

Hasil perhitungan antara subkriteria lokasi memprioritaskan mengenai lokasi pembangunan Jalan Lingkar Ambarawa yang berdekatan dengan Danau Rawa Pening sehingga terdapat pembatasan aktivitas pemanfaatan ruang dengan nilai vektor prioritas sebesar 0,984. Tabel 9 menunjukkan matriks perhitungan subkriteria lokasi.

Tabel 9. Matriks Perhitungan Subkriteria Lokasi

\begin{tabular}{cccccccc}
\hline & SC1 & SC2 & VE & VP & $\lambda$ maks & CI & CR \\
\hline SC1 & 0,075 & 0,075 & 0,150 & 0,016 & \multirow{2}{*}{2} & 0 & 0 \\
SC2 & 0,925 & 0,925 & 1,850 & $\mathbf{0 , 9 8 4}$ & & & \\
\hline
\end{tabular}

7) Prioritas Subkriteria Kelembagaan

Perhitungan pembobotan antara subkriteria kelembagaan memprioritaskan pihak pemerintah sebagai pihak yang paling memiliki wewenang dalam menentukan arahan pemanfaatan ruang di kawasan sekitar Jalan Lingkar Ambarawa karena merupakan pemangku kebijakan dengan nilai vektor prioritas sebesar 0,926 dan nilai rasio konsistensi sebesar 0,088523. Tabel 10 menunjukkan matriks perhitungan subkriteria kelembagaan.

Tabel 10. Matriks Perhitungan Subkriteria Kelembagaan

\begin{tabular}{cccccccccc}
\hline & $\mathrm{SC} 1$ & $\mathrm{SC} 2$ & $\mathrm{SC} 3$ & $\mathrm{SC} 4$ & $\mathrm{VE}$ & $\mathrm{VP}$ & $\lambda$ maks & $\mathrm{CI}$ & $\mathrm{CR}$ \\
\hline $\mathrm{SC} 1$ & 0,931 & 0,907 & 0,957 & 0,909 & 3,703 & $\mathbf{0 , 9 2 6}$ & & & \\
$\mathrm{SC} 2$ & 0,007 & 0,007 & 0,003 & 0,007 & 0,025 & 0,006 & 4,23 & 0,07 & 0,08 \\
$\mathrm{SC} 3$ & 0,012 & 0,038 & 0,017 & 0,036 & 0,104 & 0,026 & 9014 & 9671 & 8523 \\
$\mathrm{SC} 4$ & 0,049 & 0,048 & 0,023 & 0,048 & 0,168 & 0,042 & & & \\
\hline
\end{tabular}

Menurut hasil perhitungan pada subkriteria pertama, subkriteria tata ruang, diketahui bahwa para responden lebih menyetujui bahwa tidak diperlukan adanya perubahan aturan zonasi untuk pola pemanfaatan ruang untuk kawasan sekitar Jalan Lingkar Ambarawa karena kawasan tersebut akan lebih tepat apabila tetap dipertahankan sebagai kawasan nonterbangun. Ini berguna untuk melestarikan kondisi eksisting kawasan yang sebagian besar merupakan lahan pertanian serta mempertahankan luasan daerah resapan air serta daerah tangkapan air bagi Danau Rawa Pening. Kondisi ini didukung oleh hasil pembobotan untuk subkriteria biogeofisik dan subkriteria lingkungan, dimana para responden lebih memprioritaskan aspek kondisi fisik kawasan yang memiliki berbagai permasalahan serta adanya kemungkinan terjadi degradasi lingkungan di masa depan 
apabila kawasan ini dikembangkan sebagai kawasan terbangun. Pengembangan kawasan terbangun pada daerah rawan banjir tentunya tidak menguntungkan bagi masyarakat yang ingin mendirikan bangunan karena menimbulkan berbagai kerugian baik kerugian material dan non material. Oleh karena itu, masyarakat menghindari untuk mendirikan bangunan pada kawasan yang termasuk dalam rawan banjir meskipun memiliki beragam potensi, seperti kondisi topografi yang datar, kemudahan aksesibilitas, kondisi tanah yang subur dan lain sebagainya.

Berdasarkan hasil pembobotan pada subkriteria ekonomi, subkriteria potensi pemanfaatan sumber daya Danau Rawa Pening mendapat prioritas tertinggi dibandingkan dengan dua subkriteria lainnya. Hasil tersebut mengindikasikan bahwa dalam upaya menentukan arahan pemanfaatan ruang yang tepat di kawasan sekitar Jalan Lingkar Ambarawa harus memperhatikan adanya pemanfaatan sumber daya yang dimiliki Danau Rawa Pening secara maksimal agar dapat meningkatkan nilai ekonomi bagi masyarakat setempat terlebih dengan upaya untuk pemberdayaan masyarakat dalam mengelola sumber daya Rawa Pening seperti hasil tangkapan ikan serta olahan gulma eceng gondok menjadi berbagai produk kerajinan tangan yang memiliki nilai ekonomi lebih tinggi atau juga dimanfaatkan sebagai pupuk. Pembobotan prioritas berikutnya, yaitu subkriteria sosial yang berupaya mempertahankan kondisi eksisting di sekitar kawasan Jalan Lingkar Ambarawa mendapat prioritas lebih besar dibandingkan dengan kebutuhan untuk melakukan alih fungsi lahan.

Hasil pembobotan keempat subkriteria tersebut menunjukkan bahwa dari keempat responden mendukung dalam berbagai upaya yang akan dilakukan agar kawasan sekitar Jalan Lingkar Ambarawa tersebut tidak berkembang dengan tanpa terkendali menjadi kawasan terbangun serta mengesampingkan kebutuhan untuk melakukan alih fungsi lahan. Namun demikian, tidak dapat dipungkiri bahwa di kemudian hari dipastikan akan terjadi pertumbuhan penduduk dan perkembangan aktivitas di sekitar kawasan tersebut yang tentunya membutuhkan ruang terbangun untuk mengakomodasi berbagai kegiatan yang akan dilakukan.

Untuk pembobotan prioritas berikutnya pada subkriteria lokasi yang membandingkan antara lokasi pembangunan Jalan Lingkar Ambarawa yang berdekatan dengan kawasan konservasi dengan kemudahan aksesibilitas setelah dibangunnya Jalan Lingkar Ambarawa menempatkan subkriteria yang berdekatan dengan kawasan konservasi sebagai prioritas utama. Kondisi ini mengindikasikan bahwa para responden cenderung lebih menganggap bahwa lokasi pembangunan Jalan Lingkar Ambarawa yang berdekatan dengan kawasan konservasi Danau Rawa Pening tersebut memiliki pengaruh yang lebih besar agar kawasan sekitar Jalan Ambarawa tidak dikembangkan sebagai kawasan terbangun agar melindungi fungsi kawasan konservasi Danau Rawa Pening dan tidak menimbulkan dampak terhadap lingkungan sekitar. Namun demikian, tidak dapat dipungkiri bahwa dengan adanya pembangunan Jalan Lingkar Ambarawa ini akan menjadi bangkitan terhadap kemungkinan perkembangan kawasan terbangun karena adanya peningkatan kemudahan aksesibilitas dalam melakukan aktivitas. Kondisi ini sesuai dengan pendapat Oruonye (2014), Patarasuk dan Binford (2012), dan Tamin (2000) bahwa ada interaksi guna lahan dengan perkembangan jaringan jalan untuk menunjang aktivitas manusia.

Prioritas terakhir pada subkriteria kelembagaan yang membandingkan antara pihakpihak yang lebih memiliki wewenang dalam menentukan arahan pemanfaatan ruang di kawasan sekitar Jalan Lingkar Ambarawa maka dapat diketahui bahwa pihak pemerintah memiliki bobot prioritas tertinggi dengan nilai 0,926 dalam menentukan arahan pemanfaatan ruang kawasan sekitar Jalan Lingkar Ambarawa. Hal ini berkaitan dengan peran pemerintah selaku pemangku kebijakan dalam proses perencanaan pembangunan, pelaksana serta pengendali dalam implementasi program-progam pembangunan. Selain itu, pemerintah juga memiliki peran sebagai pihak yang menjembatani berbagai kepentingan 
seperti kepentingan masyarakat, akademisi, swasta dan kepentingan keberlanjutan lingkungan agar tidak terjadi tumpang tindih kepentingan. Adapun untuk prioritas kedua yang diperoleh pihak masyarakat menunjukkan adanya indikasi korelasi bahwa dalam upaya perencanaan pembangunan dan penentuan arahan prioritas pemanfaatan ruang kawasan di sekitar Jalan Lingkar Ambarawa memerlukan keterlibatan masyarakat sekitar guna mempertimbangkan pendapat atau masukan dari masyarakat selaku pihak yang lebih memahami kondisi eksisting kawasan di sekitar Jalan Lingkar Ambarawa. Adapun pihak akademisi pada prioritas ketiga mengindikasikan bahwa pihak akademisi berperan sebagai pemberi masukan dan kontrol terhadap kebijakan-kebijakan perencanan dan pengembangan wilayah yang ditetapkan oleh pemerintah. Sedangkan prioritas terakhir untuk pihak swasta mengindikasikan bahwa para pelaku usaha tidak memiliki wewenang yang besar dalam proses pengambilan keputusan suatu kebijakan perencanaan maupun program pembangunan karena para pelaku usaha harus menaati peraturan kebijakan yang telah ditetapkan oleh pemerintah. Oleh karena itu, dalam semua kegiatan pembangunan di suatu kawasan yang ingin dikembangkan oleh para pelaku usaha harus didasarkan pada kesesuaian peraturan zonasi serta perizinan agar tidak menimbulkan berbagai permasalahan di kemudian hari, seperti permasalahan lingkungan, tata ruang, sosial, ekonomi dan lain sebagainya.

\section{Penentuan Prioritas Alternatif}

Pada penentuan prioritas alternatif skenario didasarkan pada hasil pembobotan dari tiap subkriteria untuk mengetahui persepsi para responden mengenai arahan pemanfaatan ruang yang tepat untuk kawasan sekitar Jalan Lingkar Ambarawa dengan mempertimbangkan potensi dan limitasi yang dimiliki. Skenario yang telah ditentukan terdiri atas 2 macam antara lain skenario untuk mempertahankan kondisi eksisting (A1) serta skenario untuk pengembangan bersyarat (A2). Dalam hal ini yang dimaksud dengan skenario pengembangan bersyarat merupakan upaya untuk perencanaan pengembangan kawasan sekitar Jalan Lingkar Ambarawa sebagai kawasan terbangun. Akan tetapi, hal ini memerlukan kajian mendalam mengenai studi kelayakan pengembangan kawasan sekitar Jalan Lingkar Ambarawa dan hasilnya dapat diusulkan dalam revisi Rencana Tata Ruang Wilayah Kabupaten Semarang. Sedangkan untuk skenario pengembangan bersyarat adalah skenario untuk mempertahankan kondisi eksisting kawasan yang sebagian besar merupakan kawasan pertanian basah dan tidak mendukung dengan adanya alih fungsi lahan. Gambar 2 menyajikan hasil pembobotan untuk skenario alternatif menggunakan analisis AHP untuk skenario arahan pemanfaatan ruang kawasan sekitar Jalan Lingkar Ambarawa.

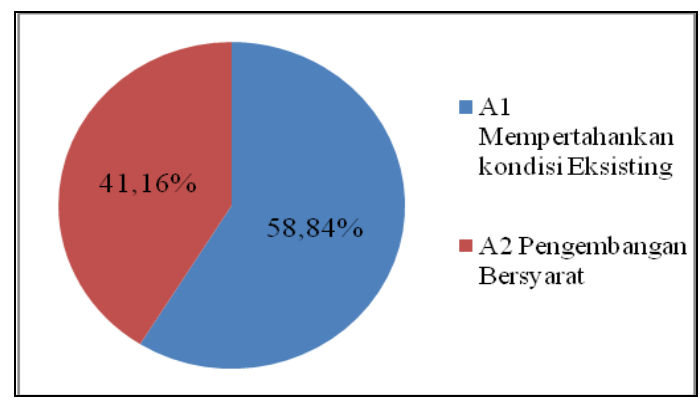

Sumber: Analisis Penyusun, 2016

Gambar 2. Diagram Prioritas Alternatif Skenario Arahan Pemanfaatan Ruang Kawasan Sekitar Jalan Lingkar Ambarawa Berdasarkan Persepsi Responden 


\section{Prioritas Arahan Pemanfaatan Ruang Kawasan Sekitar Jalan Lingkar Ambarawa berdasarkan Potensi...}

Skenario untuk mempertahankan kondisi eksisting kawasan yang mendapatkan persentase lebih tinggi dibandingkan dengan sekenario pengembangan bersyarat. Hal ini menunjukkan bahwa para responden menginginkan agar kawasan di sekitar Jalan Lingkar Ambarawa tetap dipertahankan sebagai kawasan nonterbangun dan diharapkan tidak mengalami alih fungsi lahan secara masif menjadi kawasan terbangun. Ini dikarenakan berdasarkan hasil tinjauan berbagai aspek seperti kondisi fisik lingkungan yang sebagian besar masih berupa lahan pertanian serta memiliki berbagai permasalahan fisik, seperti rawan banjir luapan dan kerusakan fisik danau sehingga dikhawatirkan akan berdampak pada terjadinya degradasi lingkungan dan berpengaruh pada eksistensi Danau Rawa Pening. Selain itu, apabila kawasan ini dikembangkan sebagai kawasan terbangun dapat berpengaruh terhadap berkurangnya pasokan hasil panen beras untuk kawasan-kawasan di sekitarnya serta berkurangnya luasan daerah tangkapan air dan daerah resapan air.

Pertimbangan lainnya yang menjadi indikasi agar mempertahankan kawasan tersebut sebagai kawasan nonterbangun adalah apabila sepanjang koridor Jalan Lingkar Ambarawa dibangun untuk berbagai peruntukkan lahan terlebih untuk aktivitas komersial maupun permukiman dikhawatirkan akan berdampak pada menurunnya kinerja jalan lingkar akibat meningkatnya hambatan samping dari kendaraan yang berhenti dan keluar masuk dari bahu jalan. Hal tersebut bertentangan dengan tujuan awal dibangunnya Jalan Lingkar Ambarawa yang mana memiliki fungsi utama sebagai jalur arteri primer yang diperuntukkan bagi kendaraan dengan kecepatan rata-rata yang tinggi. Di sisi lain, perkembangan kawasan di sekitar Jalan Lingkar Ambarawa juga dikhawatirkan akan berdampak pada perkembangan yang cenderung tidak terarah karena tidak adanya aturan mengenai jenis pemanfaatan lahan apa saja yang diperbolehkan dan tidak diperbolehkan untuk dikembangkan serta akan menghilangkan nilai estetika kawasan sekitar Jalan Lingkar Ambarawa yang selama ini memiliki keindahan panorama alam pemandangan danau, pegunungan dan persawahan disekitarnya. Hasil penentuan alternatif skenario ini juga mengindikasikan bahwa tidak diperlukan adanya perubahan peraturan zonasi untuk rencana pengembangan kawasan sebagai sebagai kawasan terbangun.

Alternatif skenario kedua adalah skenario untuk pengembangan kawasan secara bersyarat. Pengembangan secara bersyarat yang dimaksud adalah upaya untuk mengembangkan kawasan sekitar Jalan Lingkar Ambarawa sebagai kawasan terbangun dengan tetap memperhatikan batasan-batasan yang ada agar tidak menimbulkan dampak buruk bagi lingkungan sekitar terutama bagi Danau Rawa Pening dan eksistensi kawasan pertanian yang ada. Berdasarkan hasil observasi di lapangan, telaah dokumen mengenai arahan pengembangan bagi wilayah di Kabupaten Semarang, serta kajian literatur mengenai arahan pemanfaatan ruang di kawasan sekitar Danau Rawa Pening, pola pemanfaatan ruang yang paling cocok untuk dikembangkan di kawasan tersebut adalah pengembangan sebagai kawasan pariwisata. Penentuan pengembangan sebagai kawasan pariwisata juga didasarkan pada salah satu tujuan pembangunan di Kabupaten Semarang yang mana menitikberatkan pada program pengembangan INTANPARI (industri, pertanian dan pariwisata). Oleh karena itu, dengan melihat potensi yang ada, seperti potensi panorama yang indah di sepanjang koridor jalan serta adanya Danau Rawa Pening, konsep untuk pengembangan sebagai kawasan pariwisata dianggap yang paling cocok.

Untuk merencanakan pengembangan kawasan sekitar Jalan Lingkar Ambarawa sebagai kawasan pariwisata perlu menetapkan zonasi daerah mana saja yang dapat dikembangkan sebagai lokasi pembangunan objek wisata dengan mempertimbangkan berbagai kondisi di kawasan sekitar Jalan Lingkar Ambarawa. Untuk itu, perlu disusun peta usulan zonasi pengembangan pariwisata yang dapat dilihat pada Gambar 6. Peta zonasi sebagaimana tergambarkan di Gambar 6 dihasilkan melalui langkah overlay antara peta tata guna lahan eksisting, peta rawan banjir, dan peta kelerengan. Peta tata guna lahan eksisting (Gambar 3) berguna untuk mengetahui kawasan yang masih berupa lahan kosong, 
peta rawan banjir (Gambar 4) untuk mengetahui kawasan bebas banjir, dan peta kelerengan (Gambar 5) untuk mengetahui lokasi yang relatif datar.

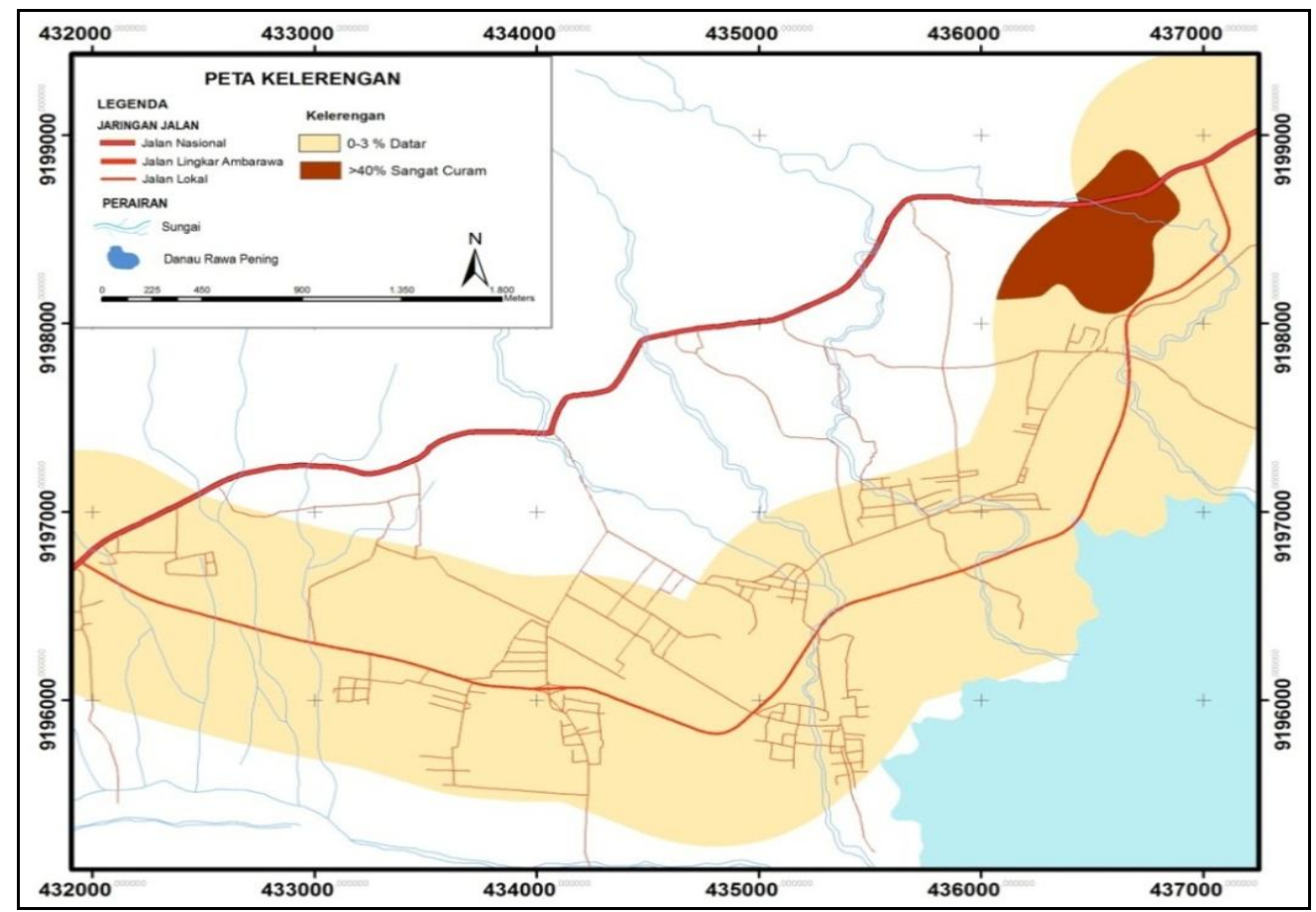

Gambar 3. Peta Kelerengan Kawasan Sekitar Jalan Lingkar Ambarawa

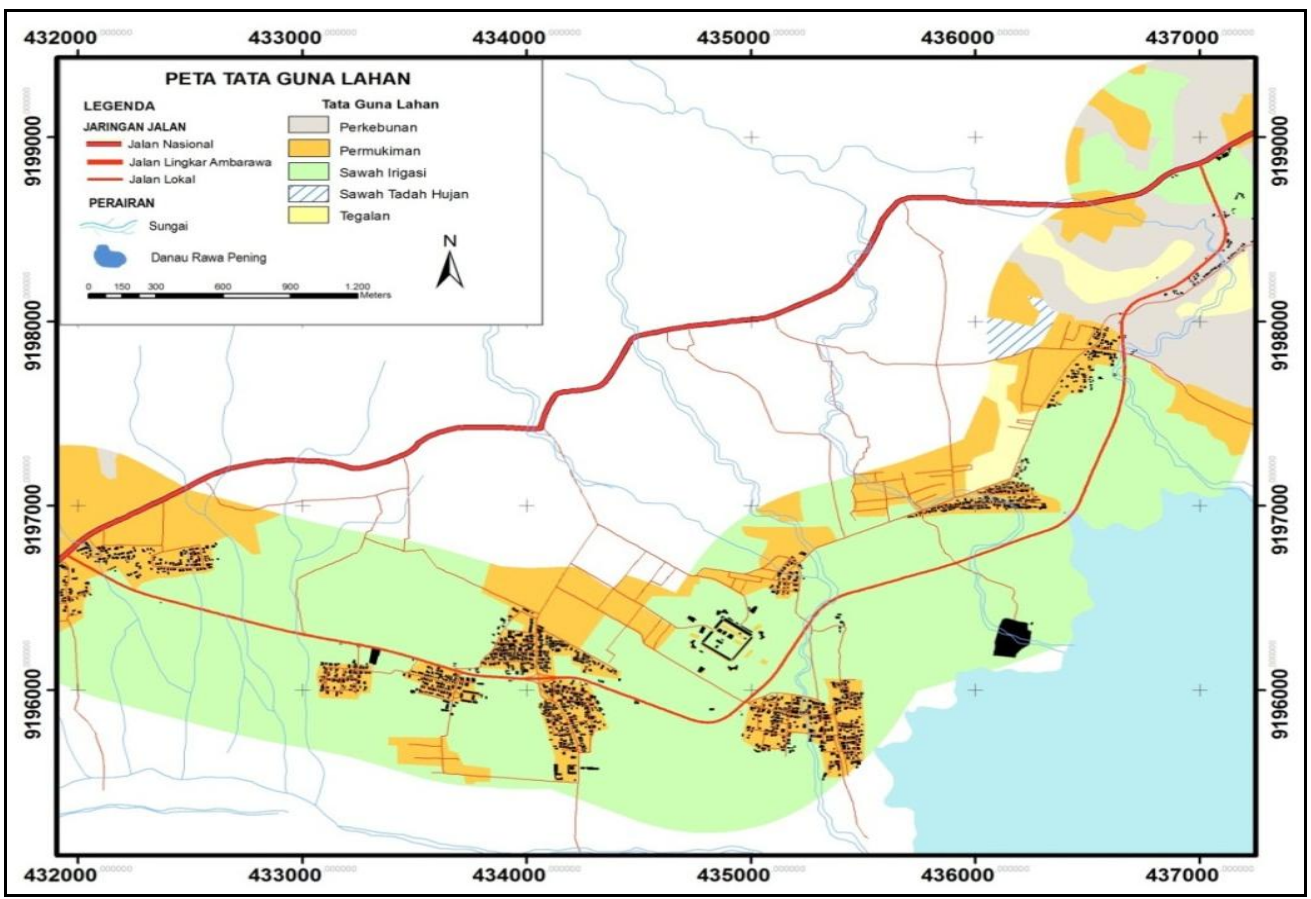

Gambar 4. Peta Tata Guna Lahan Kawasan Sekitar Jalan Lingkar Ambarawa 


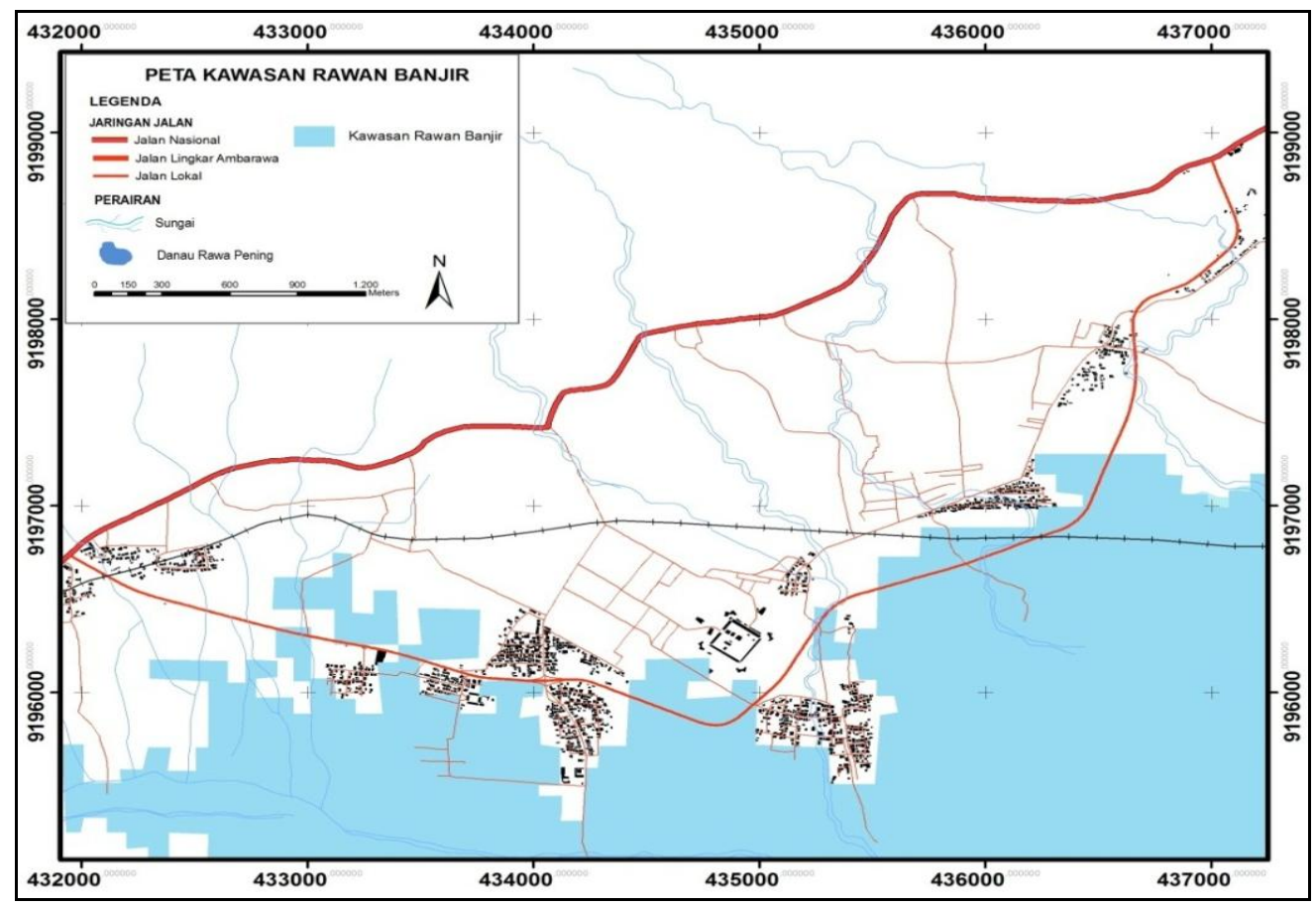

Gambar 5. Peta Rawan Banjir Kawasan Sekitar Jalan Lingkar Ambarawa

Berdasarkan hasil overlay dari ketiga peta di atas, rencana pengembangan kawasan pariwisata dapat diusulkan pada kawasan di sebelah timur serta barat Jalan Lingkar Ambarawa yang ditandai dengan warna merah. Gambar 6 adalah peta usulan zonasi pariwisata. Kawasan berwarna merah merupakan kawasan yang relatif datar, bebas dari daerah rawan banjir, serta masih berupa lahan kosong. Pada zona lainnya yang berwarna cokelat muda ini diusulkan agar tetap diperuntukkan sebagai kawasan pertanian dan permukiman eksisting sehingga tidak diperbolehkan adanya alih fungsi lahan menjadi lahan terbangun guna kepentingan pembangunan pariwisata meskipun kawasan sekitar Danau Rawa Pening memiliki potensi yang sangat besar untuk dikembangkan sebagai objek wisata. Kondisi ini sejalan dengan pendapat Rostika et al. (2012) dan Kumurur (2009) yang mengungkapkan bahwa kawasan di sekitar danau potensial untuk dikembangkan menjadi kawasan budidaya. Namun demikian, melihat eksisting di kawasan sekitar Danau Rawa Pening, akan lebih baik untuk tidak melakukan alih fungsi lahan di sekitar kawasan tersebut agar mempertahankan fungsi utama Danau Rawa Pening sebagai kawasan konservasi yang perlu dijaga kelestariannya. Ini dikarenakan terdapat korelasi antara perubahan guna lahan dengan kondisi keseimbangan ekosistem dan biodiversitas kawasan sekitar (Lawler et al., 2014). Hal ini menunjukkan bahwa tata ruang wilayah memegang peran penting dalam dalam menentukan arahan pemanfaatan ruang di kawasan sekitar Jalan Lingkar Ambarawa. 


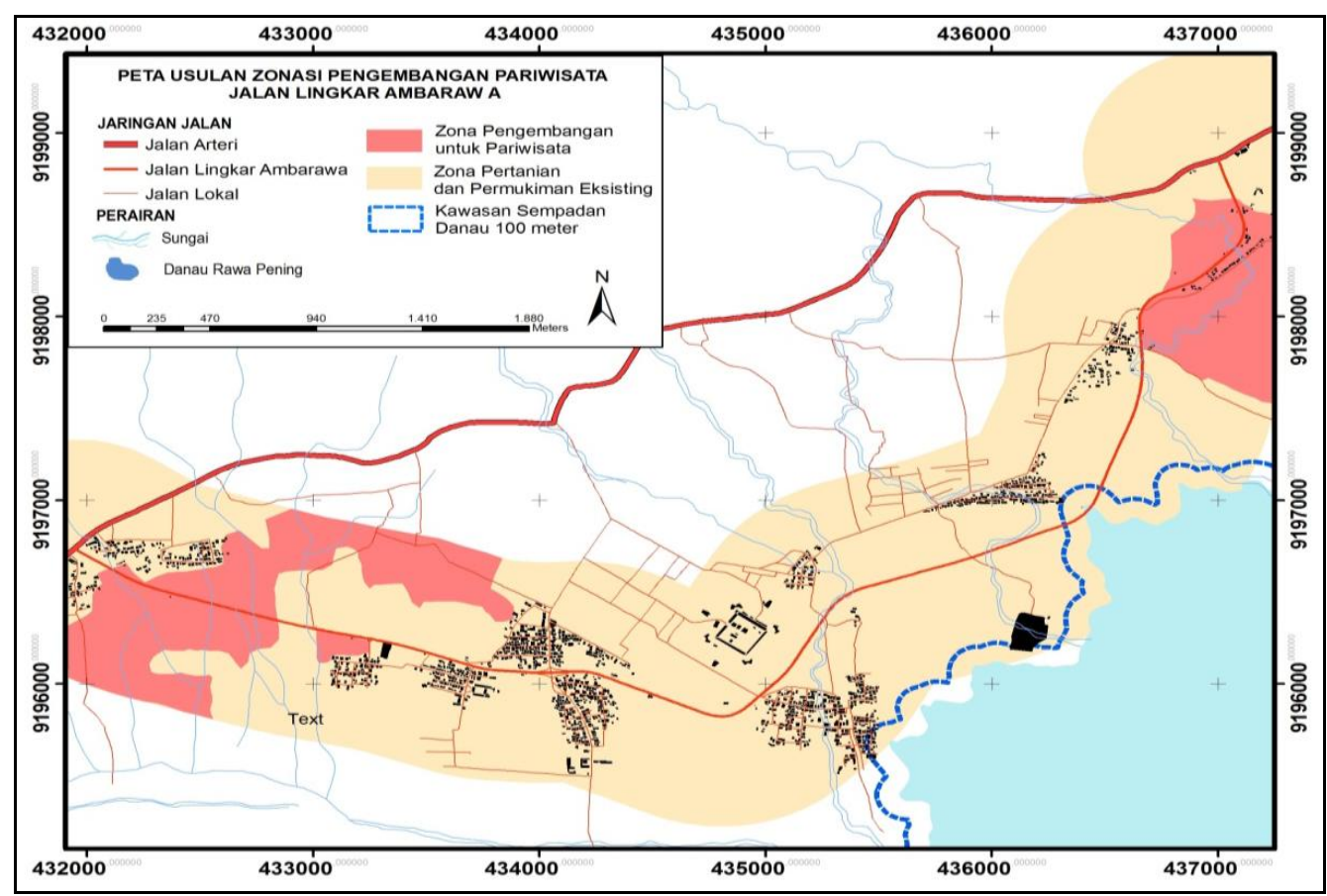

Sumber: Analisis Penyusun, 2016

Gambar 6. Peta Usulan Zonasi untuk Pengembangan Pariwisata

\section{Kesimpulan}

Berdasarkan analisis dengan menggunakan Analytic Hierarchy Process (AHP) dalam menentukan arahan pemanfaatan ruang di kawasan sekitar Jalan Lingkar Ambarawa berdasarkan persepsi para responden, didapatkan kesimpulan bahwa kriteria tata ruang merupakan kriteria utama dalam menentukan arahan pemanfaatan ruang di kawasan sekitar Jalan Lingkar Ambarawa karena Rencana Tata Ruang Wilayah (RTRW) dan rencana zonasi sudah mencakup seluruh kriteria yang berkaitan dengan rencana pengembangan dan pembangunan suatu wilayah. Seluruh hasil pembobotan untuk masingmasing subkriteria yang membandingkan antara potensi dan limitasi menunjukkan bahwa para responden lebih memperhatikan keseimbangan lingkungan dan kondisi eksisting lingkungan dibandingkan kebutuhan untuk mengubah fungsi lahan dari nonterbangun menjadi lahan terbangun. Lebih lanjut, hasil pembobotan untuk alternatif skenario pemanfaatan lahan antara skenario untuk tetap mempertahankan kondisi eksisting dibandingkan dengan skenario untuk pengembangan bersyarat mengindikasikan bahwa masih memungkinkan adanya rencana untuk pengembangan di kawasan tersebut yang perlu dikembangkan secara bersyarat. Hal ini sejalan dengan hasil tinjauan arahan pengembangan Kabupaten Semarang sebagai Kawasan INTANPARI yang menyatakan bahwa arahan pemanfaatan ruang yang cocok apabila kawasan ini ingin dikembangkan sebagai kawasan terbangun adalah sebagai kawasan pariwisata.

\section{Daftar Pustaka}

Budiharsono, S. (2005). Teknik analisis pembangunan wilayah pesisir dan lautan. Jakarta: Pradnya Paramita.

Geist, H. J., \& Lambin, E. F. (2002). Proximate causes and underlying driving forces of tropical deforestation. BioScience, 52(2), 143-150. doi:10.1641/0006-3568(2002)052[0143:PCAUDF]2.0.CO;2. 


\section{Prioritas Arahan Pemanfaatan Ruang Kawasan Sekitar Jalan Lingkar Ambarawa berdasarkan Potensi . .}

Hasim, Sapei, A., Budiharsono, S., \& Wardiatno, Y. (2012). Analisis status keberlanjutan untuk pengembangan pengelolaan pada Danau Limboto Provinsi Gorontalo. In C. Henny, M. Fakhrudin, S. H. Nasution \& T. Chrismadha (Eds.), Prosiding Seminar Nasional Limnologi VI Tahun 2012 (pp. 296-306). Bogor: Lembaga Ilmu Pengetahuan Indonesia.

Kumurur, V. A. (2009). Pengaruh perubahan pemanfaatan ruang daratan sekitar danau terhadap eutrofikasi perairan danau (Suatu studi pada pemanfaatan ruang daratan di kawasan sekitar Danau Mooat, Sulawesi Utara periode 1988-1998). Jurnal Sabua, 1(1), 9-20.

Kutarga, Z. W., Nasution, Z., Tarigan, R., \& Sirojuzilam, S. (2008). Kajian penataan ruang kawasan danau laut tawar dalam rangka pengembangan wilayah Kabupaten Aceh Tengah. WAHANA HIJAU Jurnal Perencanaan \& Pengembangan Wilayah, 3(3), 106-115.

Lawler, J. J., Lewis, D. J., Nelson, E., Plantinga, A. J., Polasky, S., Withey, J., C., . . Radeloff, V. C. (2014). Projected land-use change impacts on ecosystem services in the U.S. Proceedings of the National Academy of Sciences, 111(20), 7492-7497. doi:10.1073/pnas.1405557111.

Oruonye, E. D. (2014). An assessment of the impact of road construction on land use pattern in urban centres in Nigeria, A Case Study of Jalingo LGA, Taraba State Nigeria, Mediterranean Journal of Social Sciences, 5(10), 82-88.

Patarasuk, R., \& Binford, M. W. (2012). Longitudinal analysis of the road network development and land-cover change in Lop Buri Province, Thailand, 1989-2006. Applied Geography, 32, 228-239. doi:10.1016/j.apgeog.2011.05.009.

Pemerintah Daerah Kabupaten Semarang. Peraturan Daerah Nomor 6 Tahun 2011 tentang Rencana Tata Ruang Wilayah Kabupaten Semarang Tahun 2011-2031. Kabupaten Semarang: Pemerintah Daerah Kabupaten Semarang.

Presiden Republik Indonesia. (1982). Undang-Undang Nomor 22 Tahun 1982 tentang Tata Pengaturan Air. Jakarta: Sekretaris Negara Republik Indonesia.

Presiden Republik Indonesia. (1991). Peraturan Pemerintah Nomor 35 Tahun 1991 tentang Sungai. Jakarta: Sekretaris Negara Republik Indonesia.

Menteri Pekerjaan Umum Republik Indonesia. (2011). Peraturan Menteri Pekerjaan Umum Nomor 20/PRT/M/2011 tentang Pedoman Penyusunan Rencana Detail Tata Ruang dan Peraturan Zonasi Kabupaten Kota. Jakarta: Kementerian Pekerjaan Umum Republik Indonesia.

Saaty, T. L., \& Kearns, K. (1985). Analytical planning: The organization of systems. Oxford: Pergamon Press.

Saaty, T. L. (1991). Pengambilan keputusan bagi para pemimpin. Jakarta: PT Pustaka Binaman Pressindo.

Soeprobowati, T. R. (2012). Mitigasi danau eutrofik: Studi kasus Danau Rawa Pening. In C. Henny, M. Fakhrudin, S. H. Nasution \& T. Chrismadha (Eds.), Prosiding Seminar Nasional Limnologi VI Tahun 2012 (pp. 36-48). Bogor: Lembaga Ilmu Pengetahuan Indonesia.

Rostika, R., Avenzora, R., Masyamsir, \& Yustiati, A. (2012). Studi pengembangan pemanfaatan Danau Rawadanau di Provinsi Banten untuk budidaya perikanan dan ekowisata. In C. Henny, M. Fakhrudin, S. H. Nasution \& T. Chrismadha (Eds.), Prosiding Seminar Nasional Limnologi VI Tahun 2012 (pp. 151161). Bogor: Lembaga Ilmu Pengetahuan Indonesia.

Tamin, O. Z. (2000). Perencanaan dan permodelan transportasi. Bandung: Penerbit ITB.

Václavík, T., \& Rogan, J. (2013). Identifying Trends in land use/land cover changes in the context of postsocialist transformation in Central Europe: A case study of the Greater Olomouc Region, Czech Republic. GIScience \& Remote Sensing, 46(1), 54-76. doi:10.2747/1548-1603.46.1.54.

Verburg, P. H., van Eck, J. R. R., de Nijs, T. C. M., Dijst, M. J., \& Schot, P. (2004). Determinants of Land-Use Change Patterns in the Netherlands. Environment and Planning B: Planning and Design, 31, 125-150. doi:10.1068/b307.

Vickerman, R., Spiekermann, K., \& Wegener, M. (1999). Accessibility and economic development in Europe. Regional Studies, 33(1), 1-15. doi:10.1080/00343409950118878.

Wahyuhana, R. T., \& Sugiri, A. (2014). Kajian perencanaan tata ruang untuk memfasilitasi kegiatan nonpertanian di Kecamatan Sukorejo, Kabupaten Kendal. Jurnal Wilayah dan Lingkungan, 2(2), 169-182. doi:10.14710/jwl.2.2.169-182. 